\title{
PENGARUH KEPUASAN KERJA, KOMITMEN ORGANISASI DAN BUDAYA ORGANISASI TERHADAP ORGANIZATIONAL CITIZENSHIP BEHAVIOR
}

\author{
Nisa Mutia Dinniaty \\ Nishamutia96@gmail.com \\ Universitas Ahmad Dahlan \\ Dyah Fitriani \\ dhifa_dhe@yahoo.com \\ Universitas Ahmad Dahlan
}

\begin{abstract}
ABSTRAK
This research aims to examine the effect of job satisfaction, commitment organization and organizational culture of organizational citizenship behavior partially at PT. Telkom Indonesia Yogyakarta, this research conducted in 2 places, namely PT. Telkom Indonesia Kota Baru and PT. Telkom Indonesia Pugeran. For the distribution of questionnaires as many as 98 respondents consisting from permanent employees through two stages, namely, the first to do the distribution of validity test questionnaires of 30 respondents, and the second did the distribution of analysis test questionnaires of 68 respondents. Sampling technique in this study using Multiple Linear Regression. Validity and realibility test of the questionnaire which was used as a tool showed that the questionnare is valid and reliable for use. Test result shows the variable Job Satisfaction has a significant effect on Organizational Citizenship Behavior for PT. Telkom Indonesia. Variable Organizational Commitment has a significant effect on Organizational Citizenship Behavior for PT. Telkom Indonesia. Organizational Culture Variable significant effect on Organizational Citizenship Behavior on employees PT. Telkom Indonesia.
\end{abstract}

Keywords: Job Satisfaction, Organizational Commitment, Organizational Culture, Organizational Citizenship Behavior.

\section{PENDAHULUAN}

Pada era globalisasi seperti ini, tidak dapat dipungkiri bahwa persaingan antar prusahaan menjadi semakin ketat. Semakin banyak usaha-usaha mulai dari perusahaan yang besar sampai dengan perusahaan yang kecil menjadi salah satu faktor penyebab ketatnya persaingan antar perusahaan. Persaingan antar perusahaan tersebut tidak terkecuali juga terjadi pada PT. Telkom Indonesia Kota Baru Yogyakarta. Untuk mengahadapi situasi dan kondisi tersebut, perusahaan harus menentukan strategi dan kebijakan manajemennya, khususnya dalam bidang
Sumber Daya Manusia (SDM) kepuasan kerja (job satisfaction) dapat didefinisikan sebagai suatu perasaan positif tentang pekerjaan seseorang yang merupakan hasil dari sebuah evaluasi karakteristiknya. Kepuasan kerja dan kinerja memiliki hubungan sebab akibat. Tanpa adanya sumber daya manusia maka perusahaan tidak akan ada karena sumber daya manusia merupakan aset bagi perusahaan. Sumber daya manusia yang profesional adalah sumber daya manusia yang handal dan cakap dalam menyelesaikan tugas yang diberikan oleh perusahaan. Setiap individu pada sebuah perusahaan memiliki status sosial yang berbeda-beda, baik itu keyakinan maupun sikap dari karyawan. Perbedaan tersebut yang menjadi suatu 
tantangan bagi perusahaan dalam menghadapi status sosial yang dimiliki karyawan.

Seseorang yang merasakan kepuasan dalam bekerja tentunya ia akan berupaya semaksimal mungkin dengan segenap kemampuan yang dimiliki untuk memberikan performa terbaiknya kepada organisasi tempat ia bekerja dengan menyelesaikan tugas pekerjaannya sebaik mungkin. Bahkan, karyawan yang puasakan memiliki kesediaan untuk melakukan hal lebih diluar tanggung jawab formalnya. Kesediaan inilah yang kemudian dikenal sebagai Organizational Citizenship Behavior (OCB). Organizational Citizenship Behavior (OCB) didefinisikan sebagai pekerjaan yang berhubungan dengan perilaku yang tidak mengikat, bersifat sukarela, tidak berkaitan dengan system reward formal yang organisasi, dan secara keseluruhan meningkatkan efektivitas fungsi organisasi.

Organisasi yang mempunyai karyawan yang memiliki OCB (Oraganizational Citizenship Behavior) yang baik, akan memiliki prestasi kerja yang lebih baik. Selain itu sikap positif perilaku extra role karyawan memiliki pengaruh yang positif terhadap kepuasan kerja, komitmen organisasi, efisiensi dan efektivitas kinerja organisasi secara keseluruhan. Ada berbagai faktor yang berperan penting dalam kemunculan OCB antara lain: kepuasan kerja, komitmen organisasi, dan budaya organisasi.

Faktor utama yang mempengaruhi OCB yaitu kepuasan kerja, kepuasan kerja adalah suatu perasaan yang menyokong atau tidak menyokong diri pegawai yang berhubungan dengan pekerjaannya maupun dengan kondisi dirinya menurut (Keith Davis (1985),
Wexley dan Yuki (1977) dalam Mangkunegara (2017).

Faktor kedua, komitmen organisasi. Menurut Kaswan (2017), komitmen organisasi adalah sikap kerja dalam wujud keinginan, kemauan, dedikasi, loyalitas, dan kepercayaan yang kuat yang menunjukkan keinginan tetap menjadi bagian anggota organisasi dengan mau menerima nilai dan tujuanorganisasi, dan bekerja atas nama / untuk kepentingan organisasi.

Faktor ketiga, budaya organisasi (organization culture). Menurut Amstrong (2005) dalam Torang (2016) berorganisasi atau korporat adalah pola nilai, norma, keyakinan, sikap dan asumsi yang dapat diartikulasikan. Menurut Thompson dan Stickland (2001) dalam Torang (2016) budaya organisasi menunjukan nilai, beliefs, prinsip, tradisi dan cara sekelompok orang beraktivitas dalam organisasi.

PT. Telkom Indonesia Yogyakarta merupakan perusahaan yang bergerak dalam bidang jasa teknologi. Perusahaan ini memiliki banyak sekali target-target dalam usahanya untuk memberikan kepuasan konsumennya, sehingga perusahaan ini selalu mencari inovasiinovasi baru dalam bisnisnya. Semakin berkembangnya teknologi dan banyaknya keinginan dan kebutuhan konsumen maka semakin banyak juga yang harus dikerjakan perusahaan dan karyawan dalam PT. Telkom IndonesiaYogyakarta ini. Dalam hal ini perusahaan dituntut untuk selalu menemukan ide-ide baru yang mampu mempertahankan kesuksesan dari perusahaan ini.

PT. Telkom Indonesia Yogyakarta selalu aktif dalam melakukan promosipromosi dan terus mengembangkan produk yang dimilikinya sehingga hal ini dapat mengakibatkan timbulnya pekerjaan yang sangat padat dan terus menerus 
sehingga ditakutkan akan menimbukan dampak yang negatif terhadap karyawan.

Tujuan dari penelitian ini adalah: 1) untuk menguji pengaruh kepuasan kerja terhadap Organizational Citizenship Behavior pada karyawan PT. Telkom Indonesia Yogyakarta, 2) untuk menguji pengaruh komitmen organisasi terhadap Organizational Citizenship Behavior PT. Telkom Indonesia Yogyakarta dan 3) untuk menguji pengaruh budaya organisasi terhadap Organizational Citizenship Behavior PT. Telkom Indonesia Yogyakarta.

\section{REVIEW LITERATUR DAN HIPOTESIS}

\section{Landasan Teori}

1. Kepuasan Kerja

Kepuasan kerja adalah sikap umum terhadap pekerjaan seseorang, yang menunjukkan perbedaan antara jumlah penghargaan yang diterima pekerja dan jumlah yang mereka yakini seharusnya mereka terima (Robbins, 2003).

2. Komitmen Organisasi

$$
\text { Menurut Kaswan }
$$

komitmen organisasi adalah sikap kerja dalam wujud keinginan, kemauan, dedikasi, loyalitas, dan kepercayaan yang kuat yang menunjukkan keinginan tetap menjadi bagian anggota organisasi dengan mau menerima nilai dan tujuan organisasi, dan bekerja atas nama / untuk kepentingan organisasi.

\section{Budaya Organisasi}

Menurut Thompson dan Stickland (200) dalam Torang (2016) budaya organisasi menunjukan nilai, beliefs, prinsip, tradisi dan cara sekelompok orang beraktivitas dalam organisasi.

\section{Organizational Citizenship Behavior (OCB)}

Organizational Citizenship

Behavior (OCB) didefinisikan Organ, (1998) dalam Kaswan (2017) menyatakan perilaku individu yang bersifat diskresioner, tidak secara langsung diakui oleh system penghargaan formal dan bahwa secara agregat mempromosikan berfungsinya organisasi secara efektif. Dengan kebijaksanaan, kami maksudkan bahwa perilaku tersebut bukan persyaratan yang dapat ditegakkan dari peran atau uraian pekerjaan, yaitu syarat-syarat yang jelas dari konstruksi pekerjaan seseorang dengan organisasi; perilaku itu lebih merupakan masalah pilihan pribadi, sehingga penghilangannya pada umumnya tidak dipahami sebagai hukuman.

\section{Penelitian Terdahulu}

Waspodo (2012) dengan judul Pengaruh Kepuasan Kerja dan Iklim Organisasi Terhadap Organizational Citizenship Behavior (OCB) Karyawan pada PT. Trubus Swadaya Depok. Hasil penelitian menunjukkan bahwa, pertama tingkat OCB karyawan pada PT. Trubus Swadaya terbilang cukup baik, dan untuk kepuasan kerja dan komitmen organisasi dari karyawan juga terbilang baik. Kedua, dalam hitungan regresi linier sederhana, terdapat pengaruh yang signifikan antara kepuasan kerja dan OCB. Ketiga, iklim organisasi mempunyai pengaruh yang signifikan terhadap OCB. Keempat, kepuasan kerja dan iklim organisasi secara bersama-sama dansignifikan mempengaruhi OCB karyawan- karyawan PT. Trubus Swadaya, khususnya pada divisi redaktur pelaksana, divisi pengembangan produk, divisi pracetak, dan divisi akuntansi dan keuangan. Persentase sumbangan kepuasan kerja dan iklim organisasi terhadap OCB 
karyawan sebesar 15,7\%. Selebihnya $84.3 \%$ dipengaruhi oleh variabel lainnya yang tidak terlibat dalam model persamaan regresi linier berganda tersebut.

Oemar (2013) dengan judul Pengaruh Budaya Organisasi, Kemampuan Kerja dan Komitmen Organisasi terhadap Organizational Citizenhsip Behavior (OCB) Pegawai pada BAPPEDA Kota Pekanbaru. Hasil penelitian menunjukkan bahwa Budaya Organisasi merupakan variabel yang paling dominan berpengaruh signifikan terhadap organizational citizenship behavior (OCB) pegawai dengan nilai t-test sebesar 5,932, probabilitas Sig. 0,000 dan korelasi sebesar 0,520 atau 52\%. Sedangkan variabel kemampuan kerja nilai t-test sebesar 4,086, probabilitas Sig.0,000 dan korelasi sebesar 0,364 atau $36,4 \%$, sedangkan variabel komitmen organisasi nilai t-test sebesar 2,603, probabilitas Sig. 0,001 dan korelasi sebesar 0,221 atau 22,1\% dengan taraf kepercayaan (Alpha) sebesar $1 \%(=0,01), 5)$. Secara simultan (bersama-sama), budaya organisasi, kemampuan kerja dan komitmen organisasi mempunyai pengaruh yang signifikan terhadap organizational citizenship behavior (OCB) pegawai pada Bappeda Kota Pekanbaru. Kontribusi pengaruh yang disumbangkan ketiga variabel tersebut sebesar $62,5 \%$ dan $37,5 \%$ lagi dipengaruhi oleh variabel lain yang tidak diamati dalam penelitian in

\section{Hipotesis}

H1: Kepuasan kerja berpengaruh signifikan terhadap organizational citizenship behavior pada karyawan Telkom Indonesia Yogyakarta.
H2: Komitmen Organisasi berpengaruh signifikan terhadap organizational citizenship behavior pada karyawan Telkom Indonesia Yogyakarta.

H3: Budaya Organisasi berpengaruh signifikan terhadap organizational citizenship behavior pada karyawan Telkom Indonesia Yogyakarta.

\section{METODE PENELITIAN}

\section{Populasi dan Sampel}

Menurut Sugiyono (2018) populasi adalah wilayah generalisasi yang terdiri atas objek/subjek yang mempunyai kualitas dan karakteristik tertentu yang ditetapkan oleh peneliti untuk dipelajari dan kemudian ditarik kesimpulannya. Dalam penelitian ini, maka yang menjadi populasi adalah karyawan Telkom Indonesia Yogyakarta, dengan jumlah populasi 98 karyawan tetap.

Menurut Sugiyono (2018) sampel adalah bagian dari jumlah dan karakteristik yang dimiliki oleh populasi tersebut. Bila populasi besar, dan peneliti tidak mungkin mempelajari semua yang ada pada populasi, misalnya karena keterbatasan dana, tenaga dan waktu, maka peneliti dapat menggunakan sampel yang diambil dari populasi itu. Pada penelitian ini sampel adalah karyawan Telkom Indonesia Yogyakarta. Penelitian ini dilakukan di 2 tempat yaitu, di PT.Telkom Indonesia Kota Baru dan PT.Telkom Indonesia Pugeran dengan jumlah sampel yang diambil 98 karyawan tetap dengan melalui dua tahap yaitu, yang pertama melakukan penyebaran kuisioner uji validitas sejumlah 30 responden, dan yang kedua melakukan penyebaran kuisioner uji analisis sejumlah 68 responden. 


\section{Definisi Operasional}

1. Variabel Dependen

$$
\text { Organizational }
$$

Citizenship

Behavior (OCB) didefinisikan Organ (1998) dalam Kaswan (2017) menyatakan perilaku individu yang bersifat diskresioner, tidak secara langsung diakui oleh system penghargaan formal dan bahwa secara agregat mempromosikan berfungsinya organisasi secara efektif. Dengan kebijaksanaan, kami maksudkan bahwa perilaku tersebut bukan persyaratan yang dapat ditegakkan dari peran atau uraian pekerjaan, yaitu syarat-syarat yang jelas dari konstruksi pekerjaan seseorang dengan organisasi; perilaku itu lebih merupakan masalah pilihan pribadi, sehingga penghilangannya pada umumnya tidak dipahami sebagai hukuman.

2. Variabel Independen

a. Kepuasan Kerja

$$
\begin{aligned}
& \text { Kepuasan kerja adalah sikap } \\
& \text { umum terhadap pekerjaan } \\
& \text { seseorang, yang menunjukkan } \\
& \text { perbedaan antara jumlah } \\
& \text { penghargaan yang diterima pekerja } \\
& \text { dan jumlah yang mereka yakini }
\end{aligned}
$$

b. Komitmen Organisasi

$$
\text { Menurut Kaswan (2017) }
$$
komitmen organisasi adalah sikap kerja dalam wujud keinginan, kemauan, dedikasi, loyalitas, dan kepercayaan yang kuat yang menunjukkan keinginan tetap menjadi bagian anggota organisasi dengan mau menerima nilai dan tujuan organisasi, dan bekerja atas nama/untuk kepentingan organisasi. c. Budaya Organisasi

Menurut Thompson dan Stickland (2001) dalam Torang (2016) budaya organisasi menunjukan nilai, beliefs, prinsip, tradisi dan cara sekelompok orang beraktivitas dalam organisasi.

\section{Uji Instrumen}

1. Uji Validitas

Uji validitas digunakan untuk mengukur valid atau tidaknya suatu variable dalam kuesioner. Menurut Sugiyono (2010) valid adalah menunjukkan derajat ketepatan antara data yang sesungguhnya terjadi pada objek dengan data yang dapat dikumpulkan oleh peneliti. Uji validitas dalam penelitian ini menggunakan Uji Confirmatory Factor Analysis (CFA). CFA digunakan untuk menguji apakah suatu konstruk memiliki undimensionalitas atau apakah indikator-indikator yang digunakan dapat mengkonfirmasikan sebuah konstruk atau variabel. Analisis CFA akan mengelompokan masingmasing indikator pada beberapa faktor. Tinggi rendahnya validitas suatu instrumen kuesioner dapat diukur dengan bantuan SPSS 20 for Windows. Faktor loading adalah korelasi item-item pertanyaan dengan konstruk yang diukurnya. Jika nilai faktor loading $\geq 0,5$ maka indikator yang dimaksud valid dan signifikan dalam mengukur suatu konstruk (standardized loading factor $>$ $0,5)$.

\section{Uji Reliabilitas}

$$
\text { Menurut Adhila }
$$
reliabilitas sebenarnya adalah alat ukur mengukur suatu kuisioner yang merupakan indikator darivariabel atau konstruk. Suatu kuisioner dikatakan reliabel atau handal jika jawaban seseorang terhadap pernyataan adalah 
konsisten atau stabil dari waktu ke waktu. Jawaban responden terhadap pertanyaan ini dikatakan reliabel jika masing-masing pertanyaan dijawab secara konsisten atau jawaban tidak boleh acak oleh karena masing-masing pertanyaan hendak mengukur hal yang sama yaitu reliability. Pengukuran reliabilitas dapat dilakukan dengan cara, yaitu: One shot atau pengukuran sekali saja, disini pengukurannya hanya sekali dan kemudian hasilnya dibandingkan dengan pertanyaan lain atau mengukur korelasi antar jawaban pertanyaan. SPSS versi 20 memberikan fasilitas untuk mengukur reliabilitas dengan uji statistic cronbanch alpha $(\alpha)$. Suatu konstuk atau variabel dikatakan reliabel jika memberikan nilai Cronbanch Alpha > 0.60 .

\section{Teknik Analisis Data}

1. Analisis Regresi Berganda

Uji yang digunakan adalah uji regresi linier berganda. Dalam regresi linier berganda pengujian dilakukan karena variabel memiliki keterkaitan dantidak hanya terdiri dari dua variabel saja (Algifari, 2010).

$\mathrm{Y}=\mathrm{a}+\mathrm{b} 1 \mathrm{x} 1+\mathrm{b} 2 \times 2+\mathrm{b} 3 \mathrm{x} 3$

Keterangan:

$\mathrm{Y}=$ Organizational Citizenship

Behaviour (OCB)

$\mathrm{a}=$ Konstanta

b1 = Koefisien Kepuasan kerja

$\mathrm{X} 1=$ Kepuasan kerja

b2 = Koefisien Komitmen Organisasi

$\mathrm{X} 2=$ Komitmen Organisasi

b3 = Koefisien Budaya Organisasi

X3= Budaya Organisasi

\section{Uji Hipotesis}

1. Uji Parsial (Uji T)

Uji statistik $t$ pada dasarnya menunjukkan seberapa jauh pengaruh satu variabel independen secara individual dalam menerangkan variabel dependen. Hipotesis nol (H0) yang hendak diuji adalah apakah suatu parameter sama dengan nol, atau $\mathrm{H0}$ : = 0 yang artinya adalah apakah suatu variabel independen bukan merupakan penjelas yang signifikan terhadap variabel dependen. Hipotesis alternatifnya, parameter suatu variabel tidak sama dengan nol, atau $\mathrm{Ha}: \neq 0$ yang artinya adalah variabel tersebut merupakan penjelas yang signifikan terhadap variabel dependen (Kuncoro, 2001).

\section{Uji Koefisien Determinasi}

Koefisien determinasi dapat digunakan sebagai petunjuk untuk mengetahui sejauh mana variabel independen dapat menjelaskan variabel dependen. Besarnya koefisien determinasi adalah kuadrat dari koefisien korelasi (Algifari, 2010).

Koefisien determinasi

dimaksudkan untuk mengetahui tingkat ketepatan paling baik dalam regresi, dimana hal yang ditunjukkan oleh besarnya koefisiensi determinasi $\left(\mathrm{R}^{2}\right)$ antara 0 dan 1 . Koefisien determinasi $\left(\mathrm{R}^{2}\right)$ nol variabel independen sama sekali tidak berpengaruh terhadap variabel dependen. Apabila koefisien determinasi semakin mendekati satu, maka dapat dikatakan bahwa variabel independen berpengaruh terhadap variabel dependen. Selain itu, koefisien determinasi dipergunakan untuk mengetahui persentase perubahan. 
Deskriptif Pendidikan Terakhir

\section{HASIL PENELITIAN DAN PEMBAHASAN}

\section{Hasil Analisis Responden}

Deskriptif Jenis Kelamin

\begin{tabular}{|l|c|c|}
\hline \multicolumn{1}{|c|}{ Jenis Kelamin } & Frekuensi & Persentase $\%$ \\
\hline Wanita & 37 & 54,4 \\
\hline Pria & 31 & 45,5 \\
\hline Total & 68 & 100 \\
\hline
\end{tabular}

Berdasarkan tabel di atas dapat diketahui bahwa karyawan Telkom Indonesia Yogyakarta yang dijadikan sebagai responden sebanyak 68 orang. Data diperoleh melalui kuisioner yang diisi oleh responden menunjukkan bahwa 68 frekuensi responden pria sebesar 31 orang dengan persentase 45,5\%. Frekuensi responden wanita sebesar 37 orang dengan persentase $54,4 \%$. Jadi dapat disimpulkan bahwa mayoritas responden dalam penelitian ini adalah wanita. Deskriptif Usia

\begin{tabular}{|l|c|c|}
\hline \multicolumn{1}{|c|}{ Usia } & Frekuensi & Persentase $\%$ \\
\hline $18-30$ tahun & 7 & 10,2 \\
\hline $31-44$ tahun & 20 & 29,4 \\
\hline $45-60$ tahun & 41 & 60,2 \\
\hline Total & 68 & 100 \\
\hline
\end{tabular}

Berdasarkan tabel di atas dapat diketahui bahwa karyawan Telkom Indonesia Yogyakarta yang menjadi responden sebanyak 68 orang. Data yang diperoleh melalui kuisioner yang diisi oleh responden menunjukkan bahwa, frekuensi usia 18 - 30 tahun sebanyak 7 orang dengan presentase $10,2 \%$, frekuensi usia 31 - 44 tahun sebanyak 20 orang dengan presentase $29,4 \%$, frekuensi usia 45-66 tahun sebanyak 41 orang dengan presentase $60,2 \%$. Jadi dapat disimpulkan bahwa mayoritas usia responden dalam penelitian ini dengan frekuensi usia 4560 tahun sebanyak 41 orang dengan presentase $60,2 \%$.

\begin{tabular}{|c|c|c|}
\hline Pendidikan Terakhir & Frekuensi & Persentase $\%$ \\
\hline SMA & 10 & 14,7 \\
\hline D3 & 16 & 23,5 \\
\hline S1 & 33 & 48,5 \\
\hline $\mathrm{S} 2$ & 9 & 13,2 \\
\hline Total & 68 & 100 \\
\hline
\end{tabular}

Berdasarkan tabel di atas dapat diketahui bahwa karyawan Telkom Indonesia Yogyakarta yang menjadi responden sebanyak 68 orang. Data yang diperoleh melalui kuisioner yang diisi oleh responden menunjukkan bahwa frekuensi pendidikan terakhir SMA sebanyak 10 orang dengan presentase sebesar 14,7\%, frekuensi pendidikan terakhir D3 sebanyak 16 orang dengan presentases $23,5 \%$, frekuensi pendidikan terakhir S1 sebanyak 33 orang dengan presentase $48,5 \%$, frekuensi pendidikan terakhir S2 sebanyak 9 orang dengan presentase $13,2 \%$. Jadi dapat disimpulkan bahwa responden dalam penelitian ini yang terbanyak pendidikan terakhir S1 sebesar 33 orang dengan presentase $48,5 \%$.

Deskriptif Masa Kerja

\begin{tabular}{|l|c|c|}
\hline \multicolumn{1}{|c|}{ Masa Kerja } & Frekuensi & Persentase \% \\
\hline$<3$ tahun & 4 & 5,8 \\
\hline $3-6$ tahun & - & - \\
\hline $7-10$ tahun & 14 & 20,5 \\
\hline$>10$ tahun & 50 & 73,5 \\
\hline Total & 68 & 100 \\
\hline
\end{tabular}

Berdasarkan tabel di atas dapat diketahui bahwa karyawan Telkom Indonesia Yogyakarta yang menjadi responden sebanyak 68 orang. Data yang diperoleh menunjukkan bahwa frekuensi responden dengan masa kerja < 3tahun sebanyak 4 orang dengan presentase $5,8 \%$, frekuensi responden dengan masa kerja 7 - 10 tahun sebanyak 14 orang dengan persentase 20,5\%, frekuensi responden dengan masa kerja $>10$ tahun sebanyak 50 orang dengan persentase sebesar 73,5\%. Jadi dapat disimpulkan bahwa responden di dalam penelitian ini 
yang mendominasi dengan masa kerja > 10 tahun sebanyak 50 orang dan masa kerja 7 - 10 tahun sebanyak 14 orang.

Deskriptif Status Perkawinan

\begin{tabular}{|l|c|c|}
\hline \multicolumn{1}{|c|}{ Status Perkawinan } & Frekuensi & Persentase \% \\
\hline Belum Menikah & 4 & 5,8 \\
\hline Sudah Menikah & 64 & 94,1 \\
\hline Total & 68 & 100 \\
\hline
\end{tabular}

Berdasarkan tabel di atas dapat diketahui bahwa karyawan Telkom Indonesia Yogyakarta yang menjadi responden sebanyak 68 orang. Data yang diperoleh melalui kusioner yang diisi oleh responden menunjukkan bahwa frekuensi responden yang belum menikah sebanyak 4 orang dengan presentase 5,8\%, frekuensi responden yang sudah menikah sebanyak 64 orang dengan presentase 94,1\%. Jadi dapat disimpulkan bahwa responden dalam penelitian ini didominasi oleh karyawan yang sudah menikah.

\section{Hasil Penelitian}

1. Hasil Uji Validitas

\begin{tabular}{|c|c|c|c|c|c|}
\hline \multirow{2}{*}{ Kode } & \multicolumn{4}{|c|}{ Komponen Variabel } & \\
\cline { 2 - 5 } & $\begin{array}{c}\text { Kepuasan } \\
\text { Kerja }\end{array}$ & $\begin{array}{c}\text { Komitmen } \\
\text { Organisasi }\end{array}$ & $\begin{array}{c}\text { Budaya } \\
\text { Organisasi }\end{array}$ & $\begin{array}{c}\text { Oranizationa } \\
\text { ICitizenship } \\
\text { Behavior }\end{array}$ & \\
\hline KP1 & 0,694 & & & & Valid \\
\hline KP2 & 0,684 & & & & Valid \\
\hline
\end{tabular}

\begin{tabular}{|c|c|l|l|l|l|}
\hline KP3 & 0,717 & & & & Valid \\
\hline KP4 & 0,539 & & & & Valid \\
\hline KP5 & 0,857 & & & & Valid \\
\hline KP6 & 0,819 & & & & Valid \\
\hline KP7 & 0,771 & & & & Valid \\
\hline KP8 & 0,833 & & & & Valid \\
\hline KP9 & 0,842 & & & & Valid \\
\hline KP10 & 0,894 & & & & Valid \\
\hline K01 & & 0,840 & & & Valid \\
\hline K02 & & 0,799 & & & Valid \\
\hline K03 & & 0,879 & & & Valid \\
\hline K04 & & 0,817 & & & Valid \\
\hline B01 & & & 0,896 & & Valid \\
\hline B02 & & & 0,830 & & Valid \\
\hline B03 & & & 0,853 & & Valid \\
\hline B04 & & & 0,895 & & Valid \\
\hline B05 & & & 0,822 & & Valid \\
\hline OCB1 & & & & 0,896 & Valid \\
\hline OCB3 & & & & 0,744 & Valid \\
\hline OCB4 & & & & 0,840 & Valid \\
\hline OCB6 & & & & 0,894 & Valid \\
\hline OCB7 & & & & 0,732 & Valid \\
\hline & & & & & \\
\hline OCB9 & & & & 0,845 & Valid \\
\hline OCB11 & & & & 0,918 & Valid \\
\hline OCB12 & & & & 0,850 & Valid \\
\hline OCB13 & & & & 0,797 & Valid \\
\hline OCB14 & & & & 0,862 & Valid \\
\hline OCB15 & & & & 0,864 & Valid \\
\hline
\end{tabular}

Dari seluruh item pernyatan pada keseluruhan variabel hanya memilki 30 item pernyataan yang dapat dikatakan valid sesuai setandar yaitu memiliki nilai factor loading > 0,05 dan tidak terdapat nilai negatif.

2. Hasil Uji Reliabilitas Hasill Lji Reliabilitas

\begin{tabular}{|l|c|c|}
\hline \multicolumn{1}{|c|}{ Variabel } & Nillai Cronbach's Alphu & Status \\
\hline Kepuasan Kerja (XI) & 0,916 & Reliabel \\
\hline Komitmen Organisasi (X2) & 0,948 & Reliabel \\
\hline Budaya Organisasi (X3) & 0,911 & Reliabel \\
\hline $\begin{array}{l}\text { Organizational Citizenship } \\
\text { Behavior(Y) }\end{array}$ & 0,955 & Reliabel \\
\hline
\end{tabular}

Berdasarkan tabel di atas, dapat diketahui bahwa semua variabel dinyatakan reliabel karena semua nilai Cronbach's Alpha tiap variabel > 0,60. 
Dan variabel dependen dalam hasil uji reliabilitas juga telah menunjukan nilai chronbach alpha yang lebih besar dari 0,60 adalah 0,955. Dengan demikian, dari seluruh hasil variabel penelitian yang telah diuji tersebut menunjukan kekonsistenan antara pernyataan dengan jawaban yang diberikan oleh responden.

\section{Hasil Uji Regresi Linier Berganda}

Hasil Analisi Regresi Linier Berganda

\begin{tabular}{|c|c|}
\hline \multirow{2}{*}{ Variabel Penelitian } & $\begin{array}{c}\text { Unstandardized } \\
\text { Coefficients }\end{array}$ \\
\cline { 2 - 2 } & $\mathrm{B}$ \\
\hline (constant) & 1,190 \\
\hline Kepuasan Kerja & 0,200 \\
\hline Komitmen Organisasi & 0,349 \\
\hline Budaya Organisasi & 0,183 \\
\hline
\end{tabular}

Dari hasil linier berganda diatas, dapat diperoleh persamaan sebagai berikut:

$\mathrm{Y}=\mathrm{a}+\mathrm{b} 1 \mathrm{X} 1+\mathrm{b} 2 \mathrm{X} 2+\mathrm{b} 3 \mathrm{X} 3$

$\mathrm{Y}=1,190+0,200 \mathrm{X} 1+0,349 \mathrm{X} 2+0,183 \mathrm{X} 3$

Dari persamaan garis linear diatas, dapat diartikan bahwa:

Y: Variabel yang nilainya akaan diprediksi oleh variabel independen. Dalam penelitian ini, yang menjadi variabel dependen adalah Organizational Ctizenship Behavior, yang nilainya diprediksi oleh variabel Kepuasan Kerja, Komitmen Organisasi, dan Budaya Organisasi.

a: 1,190 merupakan nilai konstanta, dengan demikian nilai konstanta ini menunjukkan besarnya nilai Organizational Citizenship Behavior jika variabel independen sama dengan nol.

b1:0,200 koefisien bernilai positif artinya terjadi pengaruh antara variabel Kepuasan Kerja (X1) terhadap Organizational Citizenship Behavior pada karyawan di
PT.Telkom Indonesia. Jika Kepuasan Kerja (X1) semakin besar maka Organizational Citizenship Behavior (Y) akan besar juga. Artinya Kepuasan Kerja semakin meningkat maka karyawan akan setulus hati melakukan perilaku Organizational Citizenship Beahavior di tempat kerja tanpa ada paksaan maupun imbalan.

b2:0,349 koefisien bernilai positif artinya terjadi pengaruh antara variabel Komitmen Organisasi (X2) terhadap Organizational Citizenship Behavior (Y) pada karyawan di PT.Telkom Indonesia Yogyakarta. Koefisien Komitmen Organisasi (X2) sebesar 0.349 artinya bahwa Komitmen Organisasi pada karyawan sangat erat dan berkomitmen tinggi untuk terus memajukan dimana karyawan tersebut bekerja. Dengan Komitmen Organisasi yang tinggi maka perilaku OCB akan diterapkan oleh karyawan tersebut.

b3:0,183 koefisien bernilai positif artinya terjadi pengaruh antara variabel Budaya Organisasi (X3) terhadap Organizational Citizenship Behavior pada karyawan di PT.Telkom Indonesia. Jika Budaya Organisasi (X3) semakin besar maka Organizational Citizenship Behavior (Y) akan besar juga. Artinya Budaya Organisasi yang semakin meningkat maka karyawan akan berani mengambil keputusan dan menciptakan organisasi yang efektif di tempat kerja. Dengan Budaya Organisasi yang tinggi maka perilaku OCB diterapkan oleh karyawan tersebut. 
4. Hasil Uji Parsial (Uji T)

Hasil Uji t (parsial)

\begin{tabular}{|l|r|r|}
\hline \multicolumn{1}{|c|}{ Model } & \multicolumn{1}{c|}{ thitung } & \multicolumn{1}{c|}{ Sig. } \\
\hline Kepuasan Kerja & 2,701 & 0,009 \\
\hline Komitmen Organisasi & 5,311 & 0,000 \\
\hline Budaya Organisasi & 3,084 & 0,003 \\
\hline
\end{tabular}

Dari data di atas, maka diperoleh hasil analisis seperti berikut:

a. Variabel kepuasan kerja mempunyai nilai signifikan 0,009 $<0,05$. Maka dapat disimpulkan bahwa secara individual variabel kepuasan kerja berpengaruh secara signifikan terhadap variabel organizational citizenship behavior.

b. Variabel komitmen organisasi mempunyai nilai signifikan 0,000 $<0,05$. Maka dapat disimpulkan bahwa secara individual variabel komitmen organisasi berpengaruh secara signifikan terhadap variabel organizational citizenship behavior.

c. Variabel budaya organisasi mempunyai nilai signifikan 0,003 , 0,05 . Maka dapat disimpulkan bahwa secara individual variabel budaya organisasi tidak berpengaruh secara signifikan terhadap variabel organizational citizenship behavior.

5. Hasil Uji Koefisien Determinasi Hasil Uji Koefisien Determinasi $\left(\mathbf{R}^{2}\right)$

\begin{tabular}{|c|}
\hline$R$ Square \\
\hline 0,573 \\
\hline
\end{tabular}

Berdasarkan hasil analisis menunjukan nilai R2 adalah 0,573 berarti variabel yang dipilih pada variabel independen (kepuasan kerja, komitmen organisasi dan budaya organisasi) dapat menerangkan variasi variabel dependen (organizational citizenship behavior) dengan kontribusi $57,3 \%$ sedangkan sisanya $42,7 \%$ diterangkan oleh variabel lain yang tidak dimasukan dalam penelitian ini.

\section{Pembahasan}

1. Pengaruh Kepuasan Kerja terhadap Organizational Citizenship Behavior.

Hasil penelitian ini menunjukkan bahwa variabel kepuasan kerja memiliki nilai sebesar $0,009<0,05$, yang artinya bahwa variabel kepuasan kerja berpengaruh secara signifikan terhadap organizational citizenship behavior karyawan Telkom Indonesia. Dengan adanya pengaruh secara signifikan dapat diartikan bahwa, semakin tinggi kepuasan kerja yang diberikan oleh perusahaan untuk para karyawan Telkom Indonesia maka semakin tinggi pula OCB pada karyawan Telkom Indonesia begitu pula sebaliknya semakin buruk tingkat kepuasan kerja yang diberikan oleh perusahaan kepada karayawan maka tingkat OCB karyawan juga akan menurun.

2. Pengaruh Komitmen Organisasi terhadap Organizational Citizenship Behavior.

Hasil penelitian ini menunjukkan bahwa variabel komitmen organisasi memiliki nilai signifikansi sebesar $0,000<0,05$, yang artinya bahwa variabel komitmen organisasi berpengaruh secara signifikan terhadap OCB karyawan Telkom Indonesia. Dengan adanya pengaruh secara signifikan dapat diartikan bahwa, semakin tinggi komitmen organisasi yang ada dalam diri karyawan Telkom Indonesia maka semakin tinggi pula OCB pada karyawan Telkom Indonesia begitu pula sebaliknya semakin buruk komitmen organisasi yang ada dalam diri karyawan maka tingkat OCB karyawan juga akanmenurun. 
3. Pengaruh Budaya Organisasi terhadap Organizational Citizenship Behavior

Hasil penelitian ini menunjukkan bahwa variabel budaya organisasi memiliki nilai signifikansi sebesar $0,003<0,05$, yang artinya bahwa variabel budaya organisasi berpengaruh secara signifikan terhadap OCB karyawan Telkom Indonesia. Dengan adanya pengaruh secara signifikan dapat diartikan bahwa, semakin tinggi budaya organisasi yang diterapkan oleh karyawan Telkom Indonesia maka semakin tinggi pula OCB karyawan Telkom Indonesia begitu pula sebaliknya semakin buruk tingkat budaya organisasi yang diterapkan oleh karyawan maka tingkat OCB karyawan juga akan menurun.

\section{KESIMPULAN DAN SARAN}

\section{Kesimpulan}

1. Variabel Kepuasan Kerja memiliki pengaruh secara signifikan terhadap Organizational Citizenship Behavior pada karyawan PT. Telkom Indonesia Kota Baru Yogyakarta.

2. Variabel Komitmen Organisasi memiliki pengaruh secara signifikan terhadap Organizational Citizenship Behavior pada karyawan PT. Telkom Indonesia Kota Baru Yogyakarta.

3. Variabel Budaya Organisasi memiliki pengaruh secara signifikan terhadap Organizational Citizenship Behavior pada karyawan PT. Telkom Indonesia Kota Baru Yogyakarta.

\section{Saran}

1. Bagi peneliti selanjutnya

Dalam penelitian ini banyak variabel lain yang belum diteliti. Variabel lain tersebut bisa memiliki pengaruh yang lebih baik.

2. Bagi perusahaan dan karyawan

a. Hasil analisis pada kepuasan kerja. Dalam hal ini PT. Telkom Indonesia Kota Baru Yogyakarta cukup baik, namun perlu diperhatikan lagi untuk masalah gaji, gaji yang diberikan harus sesuai dengan pekerjaan yang dilakukan oleh karyawan, dan untuk penempatan kerja berdasarkan hasil penelitian masih banyak karyawan yang kurang puas, karena tidak ditempatkan sesuai keterampilan masing - masing. Maka dari itu perlu diadakan evaluasi untuk hal ini agar semakin baik.

b. Hasil analisis Komitmen Organisasi. Dalam hal ini Komitmen Organisasi di PT. Telkom Indonesia Kota Baru Yogyakarta cukup baik. Karyawan mampu menerapkan nilai nilai perusahaan pada diri individu masing-masing. Tetapi, harus ditingkatkan lagi komitmen organisasi pada karyawan agar semakin baik.

c. Hasil analisis Budaya Organisasi. Dalam hal ini Budaya Organisasi di PT. Telkom Indonesia Kota Baru Yogyakarta cukup baik. Karyawan mampu menerapkan norma dan keyakinan yang ada pada diri individu masing-masing sehingga dapat memberikan dampak positif pada perusahaan. Tetapi, harus ditingkatkan lagi budaya organisasi pada karyawan agar semakin baik. 


\section{DAFTAR PUSTAKA}

Adhilla, Fitroh, Dkk. (2014). Petunjuk Pratikum Statistik. Yogyakarta: Universitas Ahmad Dahlan.

Algifari. (2010). Statistika Deskriptif Plus. Yogyakarta: UPP STIM YKPN.

Kaswan. (2017). Psikologi Industri dan Organisasi. Bandung: Alfabeta.

Mangkunegara, Anwar Prabu. (2017). Manajemen Sumber Daya Manusia Perusahaan. Edisi ke 14. Bandung: PT. Remaja Rosdakarya.

Oemar, Yohanas. (2013). Pengaruh Budaya Organisasi, Kemampuan Kerja, dan Komitmen Organisasi Terhadap Organizational Citizenship Behavior pada BAPPEDA Kota Pekanbaru. Jurnal Aplikasi Manajemen. Vol. 11, No. 1. Hal. 6576.

Robbins, Stephen P. (2003). Perilaku Organisasi. Edisi kesembilan. Diterjemahkan oleh: Tim Indeks. Jakarta: PT. Indeks Kelompok Gramedia.

Sugiyono. (2010). Metode Penelitian Pendidikan: Pendekatan Kuantitatif Kualitatif dan $R \& D$. Bandung: PT Alfa Beta.

Torang, Syamsir. 2016. Organisasi dan Manajemen (perilaku, struktur, budaya \& perubahan organisasi). Edisi ke 3. Bandung: Alfabeta.

Waspodo, Agus Aws dan Lussy Minadaniati. (2012). Pengaruh Kepuasan Kerja dan Iklim Organisasi Terhadap Organizational Citizenship Behavior. Jurnal Riset Manajemen Sains Indonesia. Vol. 3, No.1. 1-16. 